Akreditasi KEMENRISTEKDIKTI, Nomor: 148/M/KPT/2020
http: / /jurnal.stkippersada.ac.id/jurnal/index.php/VOX

\title{
HASIL BELAJAR SISWA PADA MATERI KALOR MENGGUNAKAN BAHAN AJAR BERBASIS E-LEARNING EDMODO
}

\author{
Rahayu Utami' ${ }^{1}$ Fadillah $^{2}$, Eny Enawaty ${ }^{3}$ \\ ${ }^{1,2,3}$ Teknologi Pendidikan, Fakultas Keguruan dan Ilmu Pendidikan, Universitas Tanjungpura \\ e-mail: rahayuutami1392@gmail.com
}

\section{INFO ARTIKEL \\ Riwayat Artikel: \\ Menerima : 07 Januari 2021 \\ Revisi : 29 Maret 2021 \\ Diterima : 08 April 2021}

\section{Kata Kunci:}

E-learning; Edmodo; bahan ajar; kalor

Keywords:

E-learning; Edmodo; teaching materials; heat

\section{Korespondensi:}

Rahayu Utami

Program Studi Magister Teknologi Pendidikan, Universitas

Tanjungpura

Email:

rahayuutami1392@gmail.com

\begin{abstract}
ABSTRAK
Penelitian ini bertujuan untuk mengetahui peningkatan hasil belajar dengan menggunakan bahan ajar berbasis $e$-learning Edmodo pada materi kalor serta untuk mengetahui apakah terdapat perbedaan yang signifikan antara hasil belajar sebelum dan sesudah menggunakan bahan ajar berbasis e-learning Edmodo. Jenis penelitian ini adalah penelitian eksperimen dengan bentuk penelitian Pre-Experimental Design dan rancangan One Group PretestPosttest Design. Pengumpulan data dilakukan dengan memberikan pretest dan posttest berbentuk pilihan ganda terhadap 30 siswa kelas VIII yang dipilih secara intact group. Hasil analisis data menunjukkan terjadi peningkatan hasil belajar siswa sebesar 47.34 dan terdapat perbedaan pada hasil belajar siswa pada materi sebelum dan sesudah menggunakan bahan ajar berbasis e-learning Edmodo. Hasil belajar aspek sikap dan keterampilan siswa setelah menggunakan bahan ajar berbasis e-learning Edmodo termasuk kategori sangat baik dengan rata-rata nilai masing-masing sebesar 3.66 pada aspek sikap dan 3.8 pada aspek keterampilan.
\end{abstract}

\section{ABSTRACT}

The aims of this research is to determine increment of learning outcomes through usage of learning E-learning Edmodo-based teaching materials at Heat materials and to determine the significance difference of the learning outcomes before and after using the e-learning Edmodo-based teaching materials. Method used by this research is Pre-Experimental design with One Group Pretest-Posttest Design. Data collection held by giving pretest and posttest in the form of multiple choice questions to 30 student in grade VII which are chosen by intact group. Result of data analysis shows that there is increment of learning outcomes which is 47.34 and there is significance difference of learning outcomes before and after e-learning Edmodo is used by students. Affective and Skill Learning outcomes is categorized very good after the e-learning Edmodo-based teaching materials is used with average score of 3.66 on affective learning outcomes and 3.8 on skill learning outcomes.

\section{PENDAHULUAN}

Pembelajaran IPA merupakan sebuah proses pembelajaran di mana siswa mempelajari sebuah konsep, yang terdiri dari prinsip-prinsip serta aturan-aturan yang tersusun secara sistematis dan dituangkan dalam bentuk persamaan-persamaan matematis. Untuk menciptakan pembelajaran yang lebih baik, efektif dan berkontribusi pada hasil belajar yang bermakna maka diperlukan adanya bahan ajar yang baik, menarik dan interkatif. Bahan ajar merupakan sebuah 
susunan atas bahan-bahan yang disusun secara sistematis yang dikumpulkan dari berbagai sumber belajar (Prastowo, 2015). Dalam sebuah proses pembelajaran, bahan ajar merupakan salah satu hal yang penting guna mencapai indikator pembelajaran itu sendiri. Bahan ajar sendiri sesungguhnya dapat digunakan sesuai dengan kebutuhan dari pembelajar sehingga bahan ajar dapat menarik pembelajar untuk memperoleh pengetahuan. Penggunaan bahan ajar ini dapat dilakukan oleh guru yang telah mengenal karakteristik siswa dan gaya belajar siswa. Selain itu, pemilihan bahan ajar dalam proses pembelajaran harus sesuai dengan penyampaian poin materi agar dapat dipahami oleh siswa (Aisyah, Noviyanto, dan Triyanto, 2020).

Di era revolusi industri 4.0, terdapat berbagai perkembangan teknologi. Salah satu perkembangannya ialah di bidang pendidikan. Perkembangan ini dapat dilihat dari adanya perubahan metode dalam pembelajaran dan memperoleh informasi untuk pembelajaran. Metode pembelajaran saat ini memungkinkan pembelajar untuk melakukan proses belajar di mana saja dan kapan saja. Hal ini ditunjang dengan penggunaan internet dan ketersediaan aplikasi pembelajaran online atau yang biasa dikenal dengan aplikasi e-learning. Darmawan (2016: 10) mengemukakan bahwa e-learning merupakan aplikasi internet yang dapat menghubungkan antara pendidik dan peserta didik dalam sebuah ruang belajar online

Penggunaan aplikasi e-learning mampu membuat pembelajar atau siswa lebih leluasa dalam mengakses informasi dan melakukan interaksi antar pembelajar. Hal ini dapat membantu para pembelajar meningkatkan pengetahuan dan keterampilan mereka. Jethro et all (2012) mengungkapkan bahwa e-learning merupakan aktivitas menggunakan teknologi internet untuk meningkatkan pengetahuan dan keterampilan yang menawarkan pembelajar untuk mengontrol konten, waktu belajar, ritme belajar, dan media sehingga mereka mencapai tujuan pembelajaran mereka sendiri.

Salah satu penggunaan bahan ajar ialah dengan mengaplikasikan e-learning yang ada sehingga proses pembelajaran dapat berlangsung secara efisien dan efektif. Dengan menggunakan bahan ajar berbasis e-learning, siswa dapat meningkatkan pengetahuan secara maksimal dan dalam waktu yang singkat. Selain itu, dalam memperoleh informasi, siswa tidak lagi terbatas pada ruang dan waktu. Bahan ajar berbasis e-learning dapat diakses oleh para siswa dimana saja dan kapan saja. Di dalam proses pembelajaran e-learning, guru tidak hanya mengunggah materi pembelajaran yang bisa diakses secara online oleh peserta didik, tetapi guru juga melakukan evaluasi, menjalin komunikasi, serta mengelola aspek-aspek pembelajaran lainnya (Weni dan Isnani, 2016).

Berdasarkan wawancara, 18 dari 20 orang siswa mengungkapkan lebih sering menggunakan internet untuk mencari informasi guna menyeleasaikan tugas dari guru daripada menggunakan buku teks. Penggunaan internet secara massive oleh siswa menunjukkan bahwa siswa lebih tertarik kepada penggunaan internet untuk mencari informasi guna menyelesaikan 
tugas dari guru daripada menggunakan buku teks. Hal ini dikarenakan informasi dapat diperoleh dengan mudah, praktis, dan lebih cepat daripada menggunakan buku teks sebagai sumber belajar. Selain itu, penggunaan buku teks sebagai sumber belajar dianggap monoton oleh sebagian besar siswa dan menghabiskan lebih banyak waktu dalam menemukan informasi yang diperlukan. Beberapa siswa mengungkapkan buku teks IPA lebih sulit untuk dipahami terkait beberapa istilah yang asing bagi mereka serta rumus-rumus yang digunakan pada beberapa materi. Sehingga siswa jarang membaca buku teks yang dimiliki di rumah dan lebih cenderung menggunakan catatan dari guru untuk belajar dan informasi dari internet. Namun, beberapa siswa juga memiliki rasa tidak percaya pada kebenaran informasi yang ada atau tersedia di internet.

Selain itu, berdasarkan wawancara dengan siswa, juga diperoleh bahwa sebanyak 25\% siswa kelas VII jarang sekali berkunjung ke perpustakaan, jika bukan diarahkan oleh guru mata pelajaran. Sehingga, dapat dikatakan bahwa buku teks yang ada di perpustakaan, khususnya untuk mata pelajaran IPA jarang digunakan oleh siswa. Untuk literasi, biasanya siswa menggunakan internet dalam pencarian informasi untuk tugas karena dirasa lebih praktis dan menghemat waktu. Hal ini menunjukkan bahwa siswa lebih tertarik untuk menggunakan internet daripada buku teks sebagai bahan ajar yang ada.

Ketidaktertarikan siswa terhadap bahan ajar berdampak kepada kesulitan siswa dalam memahami konsep sehingga indikator pencapaian kompetensi pembelajaran tidak dapat dicapai secara maksimal. Salah satu materi pada pembelajaran IPA ialah materi kalor. Di dalam materi kalor sendiri terdapat beberapa indikator pencapaian kompetensi yang hendaknya dicapai melalui sebuah proses pembelajara yang tertuang ke dalam hasil belajar siswa. Hasil belajar merupakan sejumlah pengalaman yang diperoleh siswa, yang tidak hanya penguasaan konsep teori mata pelajaran saja, tetapi juga penguasaan kebiasaan, persepsi, kesenangan, minat-bakat, penyesuaian social, macam-macam keterampilan, cita-cita, keinginan dan harapan (Hidayatulah, 2015). Hasil belajar tidak hanya diukur pada aspek pengetahuan, tetapi juga pada aspek keterampilan dan juga aspek sikap.

Maka, untuk mengatasi permasalahan yang ada, digunakan bahan ajar berbasis $e$ learning Edmodo pada materi kalor. Edmodo sendiri ialah sebuah jaringan pembelajaran pendidikan yang dapat digunakan secara bebas dan aman yang digunakan untuk memberi kemudahan bagi guru untuk menciptakan dan mengelola kelas online sehingga siswa dapat bekerja dan terkoneksi dengan teman sekelas dan guru di mana saja dan kapan saja (Balasubramaniana, Jaykumar, Fukey, 2014). Selain itu, aplikasi Edmodo juga berbasis android sehingga memungkinkan siswa mendapatkan pemberitahuan khusus ketika guru mengunggah tugas ataupun bahan ajar.

Beberapa penelitian terdahulu menunjukkan hasil yang baik dengan menggunakan bahan ajar berbasis e-learning. Hidayatulah (2015) menemukan bahwa 
penggunaan bahan ajar berbasis e-learning Moodle dapat meningkatkan hasil belajar sebesar $42 \%$ pada pokok bahasan besaran dan satuan. Ini berarti pengembangan bahan ajar berbasis e-learning layak digunakan untuk meningkatkan hasil belajar IPA pesera didik SMP. Selain itu, Surjono dan Purmadi (2016) mengungkapkan bahwa pengembangan bahan ajar berbasis web dapat meningkatkan hasil belajar siswa sebesar $31,87 \%$. Sehingga dapat disimpulkan bahwa bahan ajar berbasis web dapat efektif dalam proses pembelajaran.

Penelitian ini bertujuan untuk mengetahui peningkatan hasil belajar dengan menggunakan bahan ajar berbasis e-learning Edmodo pada materi kalor. Selain itu, tujuan lain dari penelitian ini ialah untuk mengetahui apakah terdapat perbedaan yang signifikan antara hasil belajar sebelum dan sesudah menggunakan bahan ajar berbasis e-learning Edmodo.

\section{METODE PENELITIAN}

Jenis penelitian ini adalah penelitian eksperimen dengan bentuk penelitian PreExperimental Design dan rancangan One Group Pretest-Posttest Design. Desain ini digambarkan sebagai berikut.

Desain ini dapat digambarkan sebagai berikut:

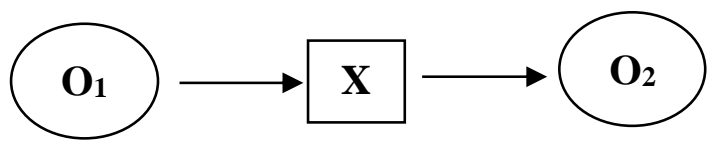

Gambar 1. One Group Pretest-Posttest Design
Analisis tes hasil belajar siswa pada aspek kognitif dilakukan dengan membandingkan antara nilai $\mathrm{O}_{2}$ dengan $\mathrm{O}_{1}$. Bila nilai $\mathrm{O}_{2}$ lebih besar daripada $\mathrm{O}_{1}$ maka produk tersebut dikatakan efektif.

Menentukan signifikansi perbedaan hasil belajar pada aspek kognitif sebelum dan setelah penggunaan bahan ajar dengan menggunakan uji t-test apabila data berdistribusi normal dan wilcoxson signed ranks test bila data yang diperoleh tidak berdistribusi normal.

Adapun hipotesis yang diuji adalah:

$\mathrm{Ha}$ : terdapat perbedaan hasil belajar sebelum dan sesudah penggunaan bahan ajar berbasis e-learning Edmodo, jika $\mathrm{P}$ value $<0,05$

Ho : tidak terdapat perbedaan hasil belajar sebelum dan sesudah penggunaan bahan ajar berbasis e-learning Edmodo, jika P value > 0,05

Pengolahan data analisis sikap dan keterampilan siswa menggunakan program Microsoft Excel untuk memperoleh nilai sikap dan keterampilan siswa sehingga dapat diketahui predikat dan kriteria sikap dan keterampilan siswa.

Analisis hasil belajar sikap dan keterampilan siswa dengan menggunakan rumus sebagai berikut.

$$
\mathrm{N}=\frac{\text { skor yang diperoleh siswa }}{\text { skor maksimal }} \times 4
$$

Setelah nilai diperoleh, langkah selanjutnya ialah menentukan predikat sikap dan keterampilan dengan tabel konversi penilaian K-13 berdasarkan Permendikbud 
nomor 104 tahun 2014 yang dapat dilihat pada tabel berikut.

\section{Tabel 1. Tabel Konversi Penilaian Sikap} dan Keterampilan

\begin{tabular}{|c|c|c|}
\hline Nilai & Predikat & Sikap/Keterampilan \\
\hline $3.83<x \leq 4.00$ & A & \multirow{2}{*}{ Sangat Baik (SB) } \\
\hline $3.50<x \leq 3.83$ & A- & \\
\hline $3.17<x \leq 3.50$ & $\mathrm{~B}+$ & \multirow{3}{*}{ Baik } \\
\hline $2.83<x \leq 3.17$ & $\mathrm{~B}$ & \\
\hline $2.50<x \leq 2.83$ & B- & \\
\hline $2.17<x \leq 2.50$ & $\mathrm{C}+$ & \multirow{3}{*}{ Cukup (C) } \\
\hline $1.83<x \leq 2.17$ & $\mathrm{C}$ & \\
\hline $1.50<x \leq 1.83$ & $\mathrm{C}-$ & \\
\hline $1.17<\mathrm{x} \leq 1.50$ & D+ & \multirow[b]{2}{*}{ Kurang (K) } \\
\hline $1.00<\mathrm{x} \leq 1.17$ & $\mathrm{D}$ & \\
\hline
\end{tabular}

Populasi dalam penelitian ini adalah siswa kelas VII SMPS Pelita Cemerlang Pontianak yang berjumlah 72 orang. Sampel diambil dengan menggunakan metoda intact group dimana sampel ditentukan secara utuh dari populasi dengan menunjuk pada pilihan kelas. Dari sejumlah kelas yang ada, kemudian dipilih secara acak satu kelompok siswa yang diikutsertakan dalam penelitian ini. Dalam penelitian ini, terdapat 30 orang siswa kelas VII SMPS Pelita Cemerlang Pontianak yang dipilih secara acak untuk dijadikan sampel.

Instrument penelitian yang digunakan dalam penelitian ini adalah berupa tes awal (pre-test) dan tes akhir (post-test), serta lembar observasi.

\section{HASIL DAN PEMBAHASAN}

Penggunaan bahan ajar berbasis $e$ learning Edmodo dalam penelitian bertujuan untuk membantu kesulitan siswa dalam memahami materi kalor. Diharapkan setelah bahan ajar berbasis e-learning Edmodo digunakan terjadi peningkatan pada hasil belajar siswa.
Hasil belajar siswa dalam hal ini terdiri dari 3 aspek, yaitu aspek kognitif, aspek afektif, dan aspek psikomotor. Aspek kognitif (pengetahuan) siswa dalam hasil belajar ini merupakan hasil penilaian pre-test dan post-test pada materi kalor yang dilakukan pada tahapan penelitian atau implementasi penggunaan bahan ajar. Pre-test diberikan kepada peserta didik sebelum menggunakan bahan ajar berbasis e-learning Edmodo, sedangkan posttest diberikan kepada peserta didik setelah peserta didik melakukan proses pembelajaran dengan menggunakan bahan ajar berbasis $e$ learning Edmodo. Kedua tes tersebut dilakukan dengan menggunakan fitur kuis yang terdapat di aplikasi Edmodo. Kedua data yang diperoleh dari pemberian kedua tes tersebut digunakan untuk melihat keefektifan dari bahan ajar berbasis e-learning Edmodo pada materi kalor. Dari hasil pre-test siswa diketahui bahwa belum ada satu pun siswa yang mencapai nilai Kriteria Ketuntasan Minimal (KKM), yakni 75. Selain itu, berdasarkan rekapitulasi diketahui bahwa nilai rata-rata 30 siswa yang mengikuti pre-test ialah 36,53. Dengan demikian, didapatkan bahwa sebanyak 30 siswa atau $100 \%$ siswa tidak mencapai KKM sebelum diadakan proses pembelajaran dengan menggunakan bahan ajar berbasis e-learning Edmodo pada materi kalor. Selanjutnya dari hasil Post-test didapati nilai rata-rata sebesar 83,87 dengan persentase ketuntasan dari 30 orang siswa ialah sebesar $73,33 \%$ atau sebanyak 22 orang siswa telah mencapai nilai KKM, yakni 75. Hal ini menunjukkan adanya peningkatan hasil belajar yang ditunjukkan 
dengan persentase ketuntasan yang mencapai $73.33 \%$, walaupun masih terdapat beberapa siswa yang memperoleh nilai di bawah KKM. Peningkatan hasil belajar ini merupakan hasil dari proses pembelajaran dengan menggunakan bahan ajar berbasis e-learning Edmodo.

Adapun perbandingan nilai rata-rata pre-test dan post-test disajikan dalam grafik di bawah ini.

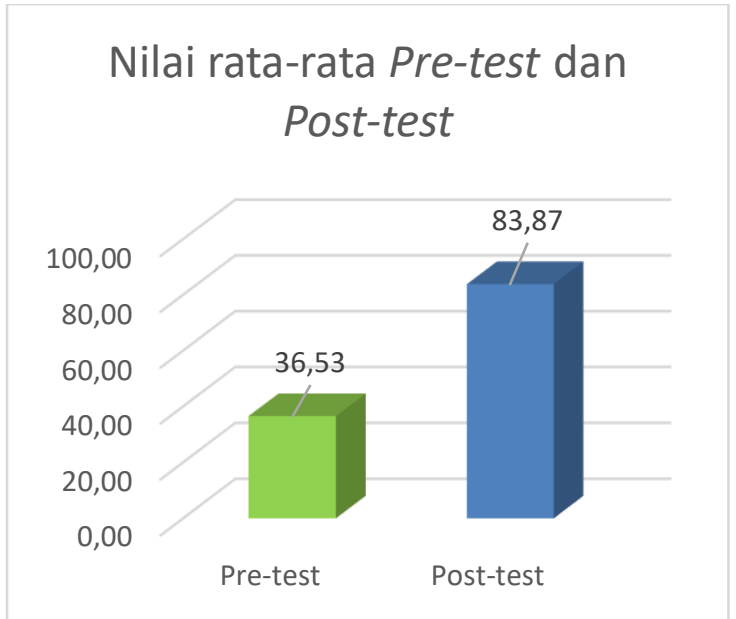

Gambar 2 Nilai Rata-Rata Pre-test dan Post-test Siswa

Berdasarkan grafik di atas, diketahui bahwa terdapat peningkatan pada nilai rata-rata hasil belajar yang berarti mengindikasikan adanya peningkatan hasil belajar siswa setelah menggunakan bahan ajar berbasis e-learning Edmodo pada materi kalor. Dari grafik di atas, diketahui bahwa nilai rata-rata pre-test atau sebelum penggunaan bahan ajar ialah sebesar 36.53 dan nilai rata-rata post-test atau setelah penggunaan bahan ajar ialah sebesar 83.87. Adanya peningkatan hasil belajar ini tidak terlepas dari rasa tertarik siswa kepada bahan ajar yang menampilkan gambar, video, dan audio yang mempermudah siswa dalam proses pembelajaran. Penggunaan media audio-visual diketahui berpengaruh signifikan terhadap hasil belajar siswa dikarenakan siswa memperoleh pengalaman dan membuat proses pembelajaran yang menyenangkan (Ege dan Simorangkir, 2012). Selain itu, hal ini juga meningkatkan keinginan siswa untuk mempelajari bahan ajar berbasis e-learning Edmodo yang diberikan. Pemakaian media dalam proses pembelajaran dapat membangkitkan keinginan dan minat yang baru, membangkitkan motivasi dan rangsangan kegiatan belajar, dan bahkan membawa pengaruh psikologis terhadap siswa (Mulyadi, 2016).

Melalui penggunaan bahan ajar berbasis e-learning Edmodo ini menunjukkan bahwa indikator pembelajaran siswa pada materi kalor dapat tercapai. Hal ini dapat terlihat dari persentasi ketuntasan siswa, di mana sebanyak $73,33 \%$ siswa tuntas KKM (Kriteria Ketuntasan Minimum) pada mata pelajaran IPA. Ini menunjukkan bahwa bahan ajar ini telah memenuhi kriteria bahan ajar yang baik. Menurut T-Tel Professional Development Programme (2016), terdapat beberapa kriteria dari bahan ajar yang baik, yaitu:

a) Bahan ajar relevan dan membantu ketercapaian tujuan pembelajaran

b) Bahan ajar memungkinkan peserta didik untuk melakukan aktivitas pembelajaran interaktif

c) Bahan ajar disiapkan oleh seorang ahli

d) Bahan ajar dapat diakses oleh semua peserta didik dengan porsi yang sama besar

e) Bahan ajar menyenangkan, informatif, dan akurat.

Guna mengetahui seberapa besar hasil belajar peserta didik setelah menggunakan 
bahan ajar berbasis e-learning Edmodo, peneliti membandingkan hasil nilai pre-test dan hasil nilai post-test siswa yang kemudian dianalisis menggunakan Uji-t. Berikut adalah tabel hasil uji-t dua sampel berpasangan dengan aplikasi SPSS versi 24.

\section{Tabel 2. Hasil Sampel Korelasi Berpasangan pada Uji t}

\begin{tabular}{rrrc}
\hline & N & Correlation & Sig. \\
\hline Pretest\&Posttest & 30 & 0.537 & 0.002 \\
\hline
\end{tabular}

Berdasarkan hasil uji-t dua sampel berpasangan dengan menggunakan aplikasi SPSS versi 24 diketahui bahwa korelasi antara nilai pretest dan posttest cukup kuat dan siginifikan. Hal ini dikarenakan nilai correlation yang ditampilkan dari hasil analisis data ialah sebesar 0.537 .

\section{Tabel 3. Hasil Uji Sampel Berpasangan pada Uji t}

\begin{tabular}{|c|c|c|c|c|c|c|c|c|}
\hline \multicolumn{9}{|c|}{ Paired Differences } \\
\hline & \multirow[b]{2}{*}{ Mean } & \multirow[b]{2}{*}{$\begin{array}{l}\text { Std. } \\
\text { Deviat } \\
\text { ion }\end{array}$} & \multirow[b]{2}{*}{$\begin{array}{l}\text { Std. } \\
\text { Error } \\
\text { Mean }\end{array}$} & \multicolumn{2}{|c|}{$\begin{array}{l}95 \% \text { Confidence } \\
\text { Interval of the } \\
\text { Difference }\end{array}$} & \multirow[b]{2}{*}{$\mathrm{t}$} & \multirow[b]{2}{*}{ df } & \\
\hline & & & & Lower & Upper & & & $\begin{array}{c}(2- \\
\text { tailed) }\end{array}$ \\
\hline $\begin{array}{l}\mathrm{Pr} \\
\text { ete } \\
\text { st- } \\
\text { Po } \\
\text { stt }\end{array}$ & -47.33 & 12.57 & 2.294 & -52.025 & -42.64 & -20.63 & 29 & 0.000 \\
\hline
\end{tabular}

Berdasarkan tabel di atas, diketahui pula bahwa terdapat perbedaan yang signifikan antara hasil belajar sebelum dan sesudah menggunakan bahan ajar berbasis e-learning Edmodo pada materi kalor dilakukan. Hal ini diketahui dari nilai Sig. (2-tailed) yang lebih kecil dari 0.05, yakni 0.000. Kemudian, bila dibandingkan $t_{\text {hitung }}$ dan $t_{\text {tabel, }}$ diketahui bahwa $t_{\text {hitung }}>t_{\text {tabel }}$ sehingga dapat sehingga dapat dikatakan Ho ditolak dan $\mathrm{Ha}$ diterima. Berdasarkan hasil ini diketahui bahwa terdapat perbedaan pada pengunaan bahan ajar berbasis e-learning Edmodo pada pembelajaran kalor sebelum dan sesudah menggunakan bahan ajar.

Selain aspek kognitif, aspek lain yang diukur oleh penliti ialah aspek psikomotor. Aspek psikomotor atau keterampilan siswa digunakan untuk mengukur kemampuan siswa dalam menggunakan perangkat elektronik dan aplikasinya, terkait pembelajaran e-learning yang dilakukan. Aspek keterampilan yang dinilai dalam penelitian ini ialah aspek hardware, aspek software, dan aspek internet.

\section{Nilai Rata-Rata Keterampilan Siswa}

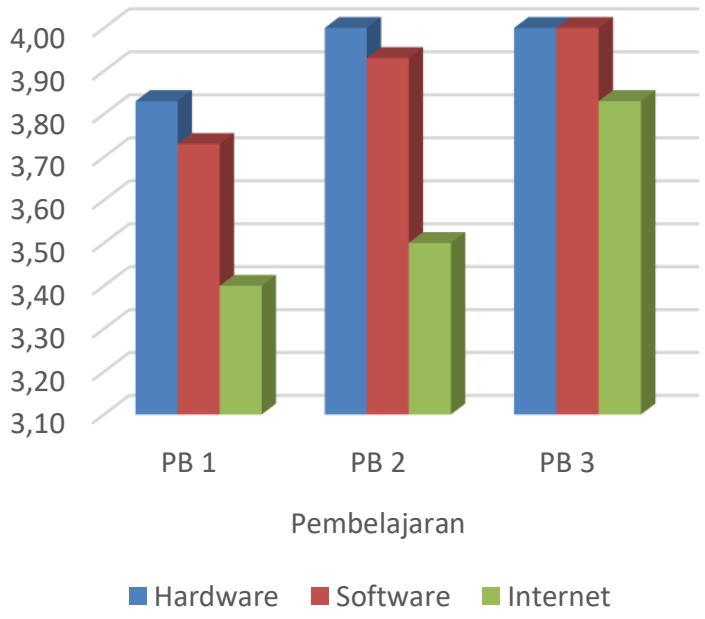

Gambar 3 Hasil Penilaian Keterampilan Siswa Berdasarkan grafik di atas, diketahui bahwa rata-rata nilai keterampilan siswa selama proses belajar 1 (PB 1), proses belajar 2 (PB 2), dan proses belajar 3 (PB 3) ialah berkisar antara 3.66 hingga 3.94. Hal ini menunjukkan bahwa keterampilan siswa mencapai kategori sangat baik. 
Aspek berikutnya yang diukur dalam hasil belajar siswa ialah aspek afektif, atau aspek sikap. Aspek afektif dalam penelitian ini digunakan untuk mengukur sikap siswa selama proses pembelajaran. Terdapat 3 aspek sikap yang dinilai, yaitu tanggung jawab, kerjasama, dan kemandirian siswa dalam proses pembelajaran. Adapun hasil observasi penilaian sikap siswa secara ringkas dapat dilihat pada grafik berikut.

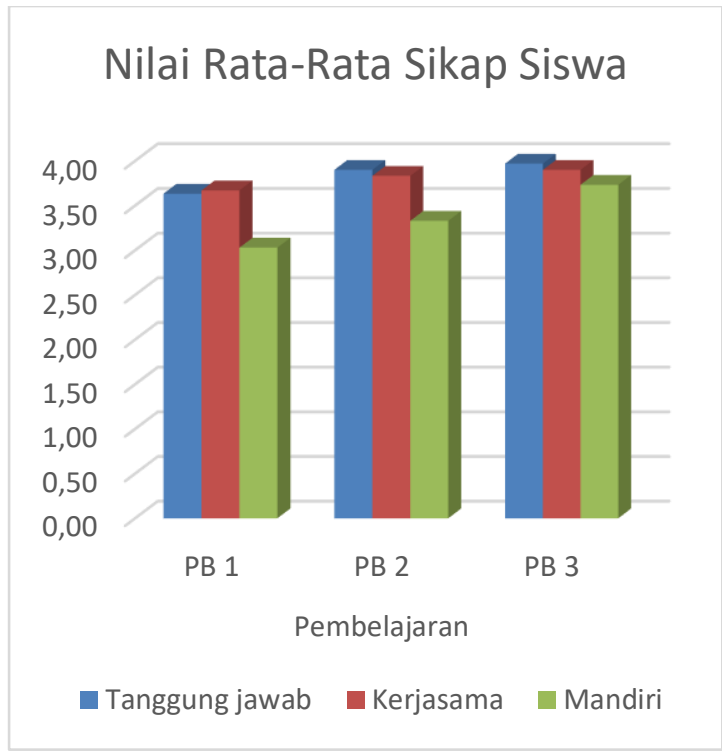

Gambar 4 Hasil Penilaian Sikap Siswa

Berdasarkan gambar di atas, diketahui bahwa nilai rata-rata sikap siswa dalam proses belajar 1 (PB 1), proses belajar 2 (PB 2), dan proses belajar 3 (PB 3) ialah berkisar antara 3.44 hingga 3.87 , yang menunjukkan bahwa sikap siswa mencapai kategori sangat baik. Dengan menggunakan aplikasi Edmodo, siswa memiliki rasa tanggung jawab lebih dalam menyelesaikan tugas dikarenakan hasil dari penilaian dapat terekap secara otomatis dan dapat dilihat secara langsung oleh siswa. Fitur kuis di dalam Edmodo memudahkan siswa dalam mengerjakan penugasan dan memotivasi siswa dalam mengerjakan penugasan. Selain itu, kerjasama siswa juga mengalami peningkatan karena di dalam bahan ajar ini, siswa diarahkan untuk melakukan diskusi, baik secara kelompok atau pun berpasangan. Hal ini merupakan aplikasi dari model pembelajaran kooperatif. Selain itu, hasil belajar pada aspek afektif juga menunjukkan peningkatan kemandirian siswa melalui penggunaan $e$ learning. E-learning dipilih dengan pertimbangan media ini ialah media yang tepat untuk mengarahkan siswa agar dapat belajar secara mandiri, dengan atau tanpa guru dalam prosesnya. Hal ini sesuai dengan pernyataan dari Wahyuningsih dan Makmur (2017) yang menyatakan bahwa e-learning memiliki fokus untuk meningkatkan kemampuan personal dan mewujudkan kemandirian belajar.

Adanya peningkatan hasil belajar siswa secara dikarenakan bahan ajar berbasis $e$ learning Edmodo ini mengkombinasikan beberapa gaya belajar siswa, yakni secara visual, auditory, dan juga kinestetik. Melalui bahan ajar ini, siswa dapat mengamati beberapa gambar yang kontekstual, menonton video, mendengarkan penjelasan melalui video, serta berinteraksi sesama peserta didik di dalam forum diskusi yang disediakan oleh fitur Edmodo. Dengan mengaplikasikan beberapa gaya belajar tersebut, siswa dapat menyerap informasi yang disajikan secara lebih mudah. Siswa memahami gaya belajar mereka sendiri seperti bagaimana memahami pelajaran dengan baik, sehingga mereka dapat menerima amteri pelajaran yang disajikan oleh guru dengan baik (Taiyeb dan Mukhlisa, 2015). Selain gaya belajar, faktor lain yang juga meningkatkan 
hasil belajar siswa melalui bahan ajar berbasis e-learning Edmodo ini ialah minat siswa akan kemajuan teknologi sehingga meningkatkan semangat dan antusias siswa dalam mempelajari materi kalor ini. Minat belajar siswa memiliki indikator diantaranya adanya perasaan tertarik dan juga senang untuk belajar, adanya partisipasi aktif, adanya kecenderungan memperhatikan dan daya konsentrasi yang besar, serta adanya rasa nyaman pada saat belajar (Yunitasari dan Hanifah, 2020).

\section{SIMPULAN}

Berdasarkan penelitian yang telah dilakukan degan menggunakan bahan ajar berbasis e-learing Edmodo pada materi kalor, dapat disimpulkan bahwa:

1. Hasil belajar siswa sebelum menggunakan bahan ajar berbasis e-learning Edmodo pada materi kalor ialah 36,53 dan setelah menggunakan bahan ajar berbasis $e$ learning Edmodo ialah 83,87 dengan kategori baik. Ini menunjukkan bahwa bahan ajar berbasis e-learning Edmodo mampu meningkatkan hasil belajar siswa pada materi kalor.

2. Terdapat perbedaan pada hasil belajar siswa pada materi dan sesudah menggunakan bahan ajar berbasis $e$ learning Edmodo dari hasil uji-t.

3. Hasil belajar aspek sikap dan keterampilan siswa setelah menggunakan bahan ajar berbasis e-learning Edmodo termasuk kategori sangat baik dengan nilai rata-rata masing-masing sebesar 3.66 dan 3.8.
4. Penggunaan bahan ajar berbasis e-learning Edmodo mampu meningkatkan kerja sama di dalam diri siswa, kemandirian, dan tanggung jawab.

\section{DAFTAR RUJUKAN}

Aisyah, Noviyanto, dan Triyanto. 2020. "Bahan Ajar Sebagai Bagian dalam Kajian Problematika Pembelajaran Bahasa Indonesia” Jurnal Salaka Vol. 2 No. 1, hal. 62-65

Balasubramaniana, Kandappan dkk. 2014. A study on "Student preference towards the use of Edmodo as a learning platform to create responsible learning environment". Procedia - Social and Behavioral Sciences Vol. 144, hal. 416 $-422$

Darmawan, Deni. 2016. Pengembangan ELearning Teori dan Desain. Bandung: PT Remaja Rosdakarya

Ege, Benediktus dan Mario Asido Simorangkir. 2012. "Pengaruh Media Audio-Visual terhadap Hasil Belajar Siswa Kelas VIII Sekolah Menengah Pertama pada Materi Sistem Peredaran Darah Manusia”Jurnal Vox Edukasi Vol. 3 No. 2, hal 72-81

Hidayatulah, Arif Harimukti dkk. 2015. Pengembangan Bahan Ajar Berbasis Web Interaktif dengan Aplikasi elearning Moodle pada Pokok Bahasan Besaran dan Satuan di SMA. Jember: FKIP Universitas Jember

Jethro, Olojo Oludare, et all. 2012. " $E$ Learning and Its Effects in Teaching and Learning in a Global Age" International Journal of Academic Research and Social Business, Vol. 2, No. 1, hal. 204.

Mulyadi, Ajang. 2016. "Pengaruh Penggunaan Media Pembelajaran 
terhadap Motivasi Belajar Siswa pada Mata Pelajaran Akuntansi” Jurnal Pendidikan Akuntansi dan Keuangan, Vol. 4 No. 1, hal. 43-49

Prastowo, Andi. 2015. Panduan Kreatif Membuat Bahan Ajar Inovatif. Jogjakarta: Diva Press

Surjono, Herman Dwi dan Ary Purmadi. 2016. "Pengembangan Bahan Ajar Berbaiss Web Berdasarkan Gaya Belajar Siswa untuk Mata Pelajaran Fisika" Jurnal Inovasi Teknologi Pendidikan Vol. 3, No 2 Oktober 2016, hal.151-165

T-TEL Professional Development Programme. 2016. Theme 5: Teaching and Learning Materials (Professional Development Guide For Student Teachers). Published by the Ministry of Education (Ghana), under Creative Commons Attribution-ShareAlike $\quad 4.0$ International. Version 1, December 2016

Taiyeb dan Mukhlisa. 2015. "Hubungan Gaya Belajar dan Motivasi Belajar dengan Hasil Belajar Biologi Siswa Kelas XI IPA SMA Negeri 1 Tanete Rilau” Jurnal Bionature Vol. 16 No. 1 April 2015, hal. 8-16

Wahyuningsih, Dian dan Rakhmat Makmur. 2017. E-Learning Teori dan Aplikasi. Bandung: Penerbit INFORMATIKA

Weni dan Isnani. 2016. "Meningkatkan Hasil Belajar Siswa dengan Pengembangan Media Pembelajaran E-Learning Berbasis Blog" Jurnal Pendidikan Bisnis dan Manajemen Vol. 2 No. 2 September 2016, hal. 114-123

Yunitasari dan Hanifah. 2020. "Pengaruh Pembelajaran Daring terhadap Minat Belajar SIswa pada Masa COVID-19" Jurnal Ilmu Pendidikan Vol. 2 No. 3, hal. 232-243 